\title{
Article \\ Microstructure and Mechanical Properties of Novel Lightweight TaNbVTi-Based Refractory High Entropy Alloys
}

\author{
Ao Fu ${ }^{1,2}$, Yuankui Cao ${ }^{1, *(1)}$, Yuxi Liu ${ }^{1}$ and Shenghang $\mathrm{Xu}^{3}$ \\ 1 State Key Laboratory of Powder Metallurgy, Central South University, Changsha 410083, China; \\ iceiceice_isu@hotmail.com (A.F.); yuxiliu@csu.edu.cn (Y.L.) \\ 2 Institute of Laser Advanced Manufacturing, Zhejiang University of Technology, Hangzhou 310023, China \\ 3 College of Materials Science and Engineering, Zhejiang University of Technology, Hangzhou 310014, China; \\ shenghangxu@zjut.edu.cn \\ * Correspondence: caoyuankui@csu.edu.cn
}

check for updates

Citation: Fu, A.; Cao, Y.; Liu, Y.; Xu, S Microstructure and Mechanical Properties of Novel Lightweight TaNbVTi-Based Refractory High Entropy Alloys. Materials 2022, 15, 355. https://doi.org/10.3390/ ma15010355

Academic Editor: Amir Mostafaei

Received: 18 November 2021

Accepted: 25 December 2021

Published: 4 January 2022

Publisher's Note: MDPI stays neutral with regard to jurisdictional claims in published maps and institutional affiliations.

Copyright: (C) 2022 by the authors. Licensee MDPI, Basel, Switzerland. This article is an open access article distributed under the terms and conditions of the Creative Commons Attribution (CC BY) license (https:// creativecommons.org/licenses/by/ $4.0 /)$.

\begin{abstract}
A series of novel lightweight TaNbVTi-based refractory high entropy alloys (RHEA) were fabricated through ball-milling and spark plasma sintering (SPS). The reinforced phase of TiO precipitates were in-situ formed due to the introduction of $\mathrm{Al}_{2} \mathrm{O}_{3}$ ceramic particles. The RHEA with $15 \% \mathrm{Al}_{2} \mathrm{O}_{3}$ exhibits a high compressive yield strength $(1837 \mathrm{MPa})$ and a low density $\left(7.75 \mathrm{~g} / \mathrm{cm}^{3}\right)$ with an adequate ductility retention. The yield strength and density are $32 \%$ higher and $15 \%$ lower, respectively, compared to the RHEA without $\mathrm{Al}_{2} \mathrm{O}_{3}$ addition. The specific yield strength $\left(237 \mathrm{MPa} \mathrm{cm}^{3} / \mathrm{g}\right.$ ) of the RHEAs is much higher than that of other reported RHEAs, and is mainly ascribed to the introduction of high volume fraction of $\mathrm{Al}_{2} \mathrm{O}_{3}$ additives, resulting in solid solution strengthening and precipitation strengthening. Meanwhile, the ductile matrix is responsible for the good compressive plasticity.
\end{abstract}

Keywords: refractory high entropy alloy; microstructure; powder metallurgy; sintering; mechanical property

\section{Introduction}

High entropy alloys (HEAs) are generally consisted of four or more principal elements in either equi-atomic or near equi-atomic composition, and tend to form simple solid solution structures, e.g., face-centered cubic (fcc), body-centered cubic (bcc) and or hexagonal close-packed (hcp), instead of complex phases or intermetallic compounds [1,2]. HEAs have recently received much attention owing to their unprecedented promising properties, such as outstanding strength, excellent fracture toughness, remarkable wear and corrosion resistance, etc. [2-6]. This concept provides enormous capabilities for the development of novel alloys for application in extreme environments [3,7]. Recently, refractory high entropy alloys (RHEAs) consisted of refractory elements, such as $\mathrm{W}, \mathrm{Mo}, \mathrm{Ta}, \mathrm{Nb}, \mathrm{V}, \mathrm{Ti}, \mathrm{Zr}$, etc., have attracted increasing attention by virtue of their superior mechanical properties at room and elevated temperature [8-11]. Unfortunately, their high density (up to $10-14 \mathrm{~g} / \mathrm{cm}^{3}$ ) and consequent low specific strength restrict their engineering application.

Adding lightweight elements into RHEAs can effectively reduce the density and improve the specific strength [12-15]. For example, Senkov et al. fabricated $\mathrm{Al}_{0.4} \mathrm{Hf}_{0.6} \mathrm{NbTaTiZr}$ RHEA by adding $\mathrm{Al}$ into the HfNbTaTiZr RHEA. The density of the alloy decreased from 9.94 to $9.05 \mathrm{~g} / \mathrm{cm}^{3}$, and the specific yield strength increased from 93.56 to $203.43 \mathrm{MPa} \cdot \mathrm{cm}^{3} / \mathrm{g}$ [16]. However, their plasticity deteriorated significantly. Recently, Yang et al. found that $\mathrm{NbTiVTaAl} l_{0.25}$ RHEA with $\mathrm{Al}$ addition still have outstanding compressive plasticity greater than $50 \%$ [17]. Nevertheless, the specific strength of this alloy is only $151.48 \mathrm{MPa} \cdot \mathrm{cm}^{3} / \mathrm{g}$, which has the potential for further improvement. In this work, a series of lightweight TaNbVTi-based RHEAs were fabricated by mechanical alloying (MA) fol- 
lowed by spark plasma sintering (SPS). The microstructural evolution and its effects on mechanical properties were analyzed.

\section{Experimental Procedures}

The TaNbVTi-based RHEAs were prepared by powder metallurgy $(\mathrm{P} / \mathrm{M})$ method. High purity (>99.5 wt.\%) Ta, Nb, V, Ti elemental powders in equiatomic composition were mixed with $\mathrm{Al}_{2} \mathrm{O}_{3}$ powders as the raw materials, and then blended with a planetary ball-millers for $6 \mathrm{~h}$ at $120 \mathrm{rpm}$ under argon atmosphere at a temperature of $25{ }^{\circ} \mathrm{C}$. The average particle size of $\mathrm{Ta}, \mathrm{Nb}, \mathrm{V}$, Ti and $\mathrm{Al}_{2} \mathrm{O}_{3}$ powders is $24.5 \mu \mathrm{m}, 26.1 \mu \mathrm{m}, 22.6 \mu \mathrm{m}$, $29.1 \mu \mathrm{m}$ and $0.3 \mu \mathrm{m}$, respectively. The content of interstitial impurities of these powders are listed in Table 1 . In this work, three volume fractions of $\mathrm{Al}_{2} \mathrm{O}_{3}$ powders $(0 \%, 10 \%$ and $15 \%)$ were added to in-situ generate particles reinforced RHEAs, namely, TaNbVTi- 0 , TaNbVTi- 1 and TaNbVTi-2, respectively. Figure 1 shows the morphology of the as-milled powders. The average particle size and chemical composition of these powders are given in Table 2. It can be seen that all these powders are in irregular shape. The content of $\mathrm{Al}$ and $\mathrm{O}$ in the as-milled powders increases with the increase of $\mathrm{Al}_{2} \mathrm{O}_{3}$ powders. Finally, the as-milled powders were consolidated via SPS machine (FCT HP D 25/3,Frankenblick, German) at $1700{ }^{\circ} \mathrm{C}$ with a heating rate of $100{ }^{\circ} \mathrm{C} / \mathrm{min}$. The sintering process was held for $10 \mathrm{~min}$ with a constant pressure of $30 \mathrm{MPa}$. The dimension of the sintered bulks is $10 \mathrm{~mm}$ in height and $40 \mathrm{~mm}$ in diameter.

Table 1. Average particle size and content of elements $\mathrm{C}, \mathrm{H}, \mathrm{O}$ and $\mathrm{N}$ in the raw powders.

\begin{tabular}{cccccc}
\hline Raw Powders & Average Particle Size $(\boldsymbol{\mu m})$ & $\mathbf{C}(\mathbf{w t} . \%)$ & O (wt.\%) & H (wt.\%) & N (wt.\%) \\
\hline $\mathrm{Ta}$ & 24.5 & 0.020 & 0.130 & 0.0008 & 0.0064 \\
$\mathrm{Nb}$ & 26.1 & 0.011 & 0.340 & 0.0015 & 0.0220 \\
$\mathrm{~V}$ & 22.6 & 0.028 & 0.290 & 0.0014 & 0.0096 \\
$\mathrm{Ti}$ & 29.1 & 0.018 & 0.280 & 0.0147 & 0.0150 \\
$\mathrm{Al}_{2} \mathrm{O}_{3}$ & 0.3 & 0.013 & 16.56 & 0.0653 & 0.0070 \\
\hline
\end{tabular}
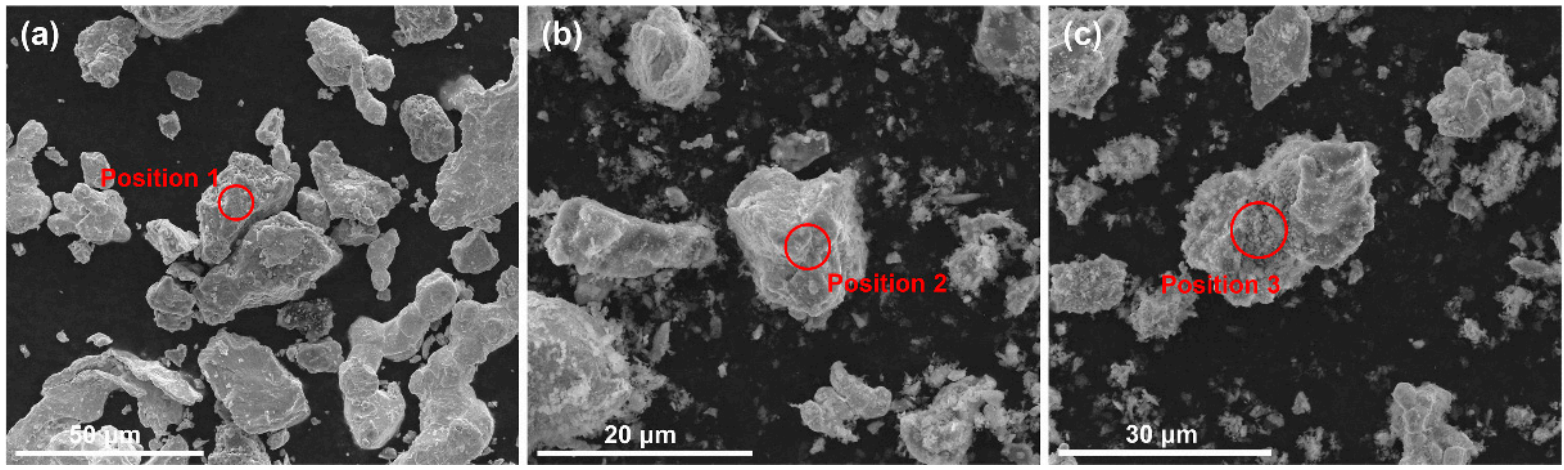

Figure 1. Morphology of the as-milled powders. (a) TaNbVTi-0, (b) TaNbVTi-1 and (c) TaNbVTi-2 powders.

Table 2. Average particle size and chemical composition of the as-milled TaNbVTi-0, TaNbVTi-1 and TaNbVTi-2 powders.

\begin{tabular}{cccccccc}
\hline As-Milled Powders & Average Particle Size $(\boldsymbol{\mu m})$ & Nb (at.\%) & Ta (at.\%) & Ti (at.\%) & V (at.\%) & Al (at.\%) & O (at.\%) \\
\hline TaNbVTi-0 & 21.5 & 22.66 & 27.61 & 24.25 & 23.17 & 0 & 2.31 \\
TaNbVTi-1 & 23.2 & 19.27 & 23.39 & 20.33 & 19.58 & 6.73 & 10.70 \\
TaNbVTi-2 & 24.3 & 17.47 & 22.21 & 18.57 & 17.67 & 9.72 & 14.37 \\
\hline
\end{tabular}

The oxygen content was determined by the fusion method on a Leco O/N analyzer. The composition was analyzed by chemical methods. The particle size distribution was investigated by a laser particle size analyzer (MICRO-PLUS). The phase analysis was performed by an X-ray diffraction analyses (XRD, Advance D8, Billerica, MA, USA) with Cu 
Ka radiation. The XRD analyses were conducted at a $2 \theta$ from $10-80^{\circ}$ with a scan rate of $5^{\circ} / \mathrm{min}$. The microstructure was characterized by a scanning electron microscope (SEM, Helios Nanolab 600i, Hillsboro, OR, USA) equipped with a backscatter electron (BSE) detector and an energy dispersive X-ray spectroscopy (EDX) device. The elemental distribution was analyzed by an electron probe microanalysis (EPMA, JXA 8530F, Tokyo, Japan). The density of the specimens was measured by Archimedes method. Cubic specimens with a dimension of $8 \mathrm{~mm} \times 8 \mathrm{~mm} \times 8 \mathrm{~mm}$ for density test were obtained from the center of the sintered bulks. Three samples were tested for the same composition, and the average value was adopted. Cylindrical specimens $(\Phi 6 \mathrm{~mm} \times 9 \mathrm{~mm})$ for compressive test were cut from the sintered bulks by using an electrical discharge machining. Before testing, the surface of test specimens was polished by a 2000-grit $\mathrm{SiC}$ paper to eliminate scratches. Room temperature compressive test was carried out on a universal testing machine (Instron-3369, Norwood, MA, USA) at a strain rate of $1 \times 10^{-3} \mathrm{~s}^{-1}$. All the specimens were compressed until fracture. Tensile tests were carried out on an MTS Landmark test machine at a strain rate of $1 \times 10^{-3} \mathrm{~s}^{-1}$ by using "I" sharp samples with a gauge length of $10 \mathrm{~mm}$ and a rectangular cross-section of $2 \mathrm{~mm} \times 2 \mathrm{~mm}$.

\section{Results and Discussion}

Figure 2 shows the XRD pattern of the sintered bulks. It is evident that the TaNbVTi-0 RHEA exhibits a single-phase $\mathrm{BCC}$ structure, and the related lattice parameter is determined to be $\sim 0.323 \mathrm{~nm}$. After the addition of $\mathrm{Al}_{2} \mathrm{O}_{3}$, some extra diffraction peaks are detected in the TaNbVTi-1 RHEA, and the intensity increased as the increase of $\mathrm{Al}_{2} \mathrm{O}_{3}$ addition, indicating more second phase forms in the TaNbVTi-2 RHEA. According to the JCPDS cards (No. 72-0020), the second phase can be identified as $\mathrm{TiO}$ phase, implying the formation of $\mathrm{TiO}$ phase in the sintered bulks, which is consistent with the results reported by Xin et al. [18].

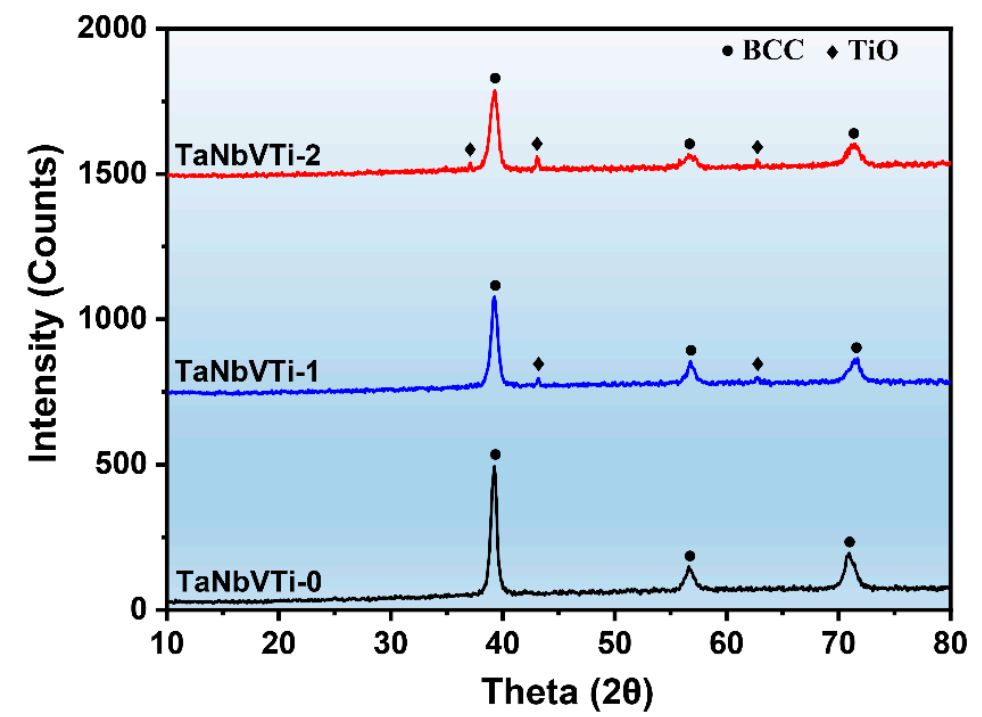

Figure 2. XRD patterns of the sintered TaNbVTi-0, TaNbVTi-1 and TaNbVTi-2 RHEAs.

Figure 3 shows the density and microstructural evolution of the as-sintered bulks. It can be seen that the density of the bulks decreases rapidly from $9.08 \mathrm{~g} / \mathrm{cm}^{3}$ of TaNbVTi-0 RHEA to $7.75 \mathrm{~g} / \mathrm{cm}^{3}$ of TaNbVTi-2 RHEA with the incremental $\mathrm{Al}_{2} \mathrm{O}_{3}$ addition. The embedded images show the microstructural characteristic of the TaNbVTi-0, TaNbVTi-1 and TaNbVTi-2 RHEAs. After sintering, the bulks can be consolidated to nearly full dense, and there are few residual pores or shrinkage defects in the microstructure. Slight component segregation can be observed in the TaNbVTi-0 RHEA, and the microstructure is composed of two distinguishable regions, bright regions and dark regions, indicating an incomplete alloying process. Figure 4 shows the EPMA mapping of the TaNbVTi-0 RHEA. The bright regions are enriched in Ta while the dark regions are enriched in $\mathrm{Ta}, \mathrm{Nb}$ and $\mathrm{V}$, 
which is consistent with the results reported by Guo et al. [8]. After addition of 10 vol.\% $\mathrm{Al}_{2} \mathrm{O}_{3}$, a large number of particles can be clearly found in the TaNbVTi-1 RHEA (Figure 3). The volume fraction of particles increases significantly with more addition of $\mathrm{Al}_{2} \mathrm{O}_{3}$ in TaNbVTi-2 RHEA, which is consist with previous XRD results. As shown in Figure 3 , the microstructure of the TaNbVTi-1 and TaNbVTi-2 RHEAs exhibits two distinguishable regions: one is dark matrix, and the other is black particle. The details of the elemental distribution of the two regions in the TaNbVTi-2 RHEA are investigated by EPMA mapping (Figure 5). According to the results, the black regions with distinct boundaries are enrich in $\mathrm{Ti}$ and $\mathrm{O}$. It has been widely reported that $\mathrm{Al}$ and $\mathrm{O}$ elements are introduced from the initial $\mathrm{Al}_{2} \mathrm{O}_{3}$ powders during the MA process [19-21]. Then the $\mathrm{Ti}$ in the matrix is favorable to react with $\mathrm{O}$ to form $\mathrm{TiO}$ particles when the sintering temperature is higher than $1057^{\circ} \mathrm{C}$ [18], which leads to the decrease of Ti content in the matrix significantly. The $\mathrm{TiO}$ particles can hinder the movement of dislocations, leading to the strength enhancement by precipitation strengthening effect $[22,23]$. Meanwhile, $\mathrm{Al}$ atoms decomposed from $\mathrm{Al}_{2} \mathrm{O}_{3}$ diffuse and dissolve into the matrix, and so that the dark regions are enriched in $\mathrm{Ta}, \mathrm{Nb}, \mathrm{V}$, $\mathrm{Ti}$ and $\mathrm{Al}$, but depleted in $\mathrm{O}$. Since misfit volume of $\mathrm{Al}$ is large, a small amount of interstitial $\mathrm{Al}$ atoms will cause remarkable solid solution strengthening effect, and thereby resulting in strength improvement [24].

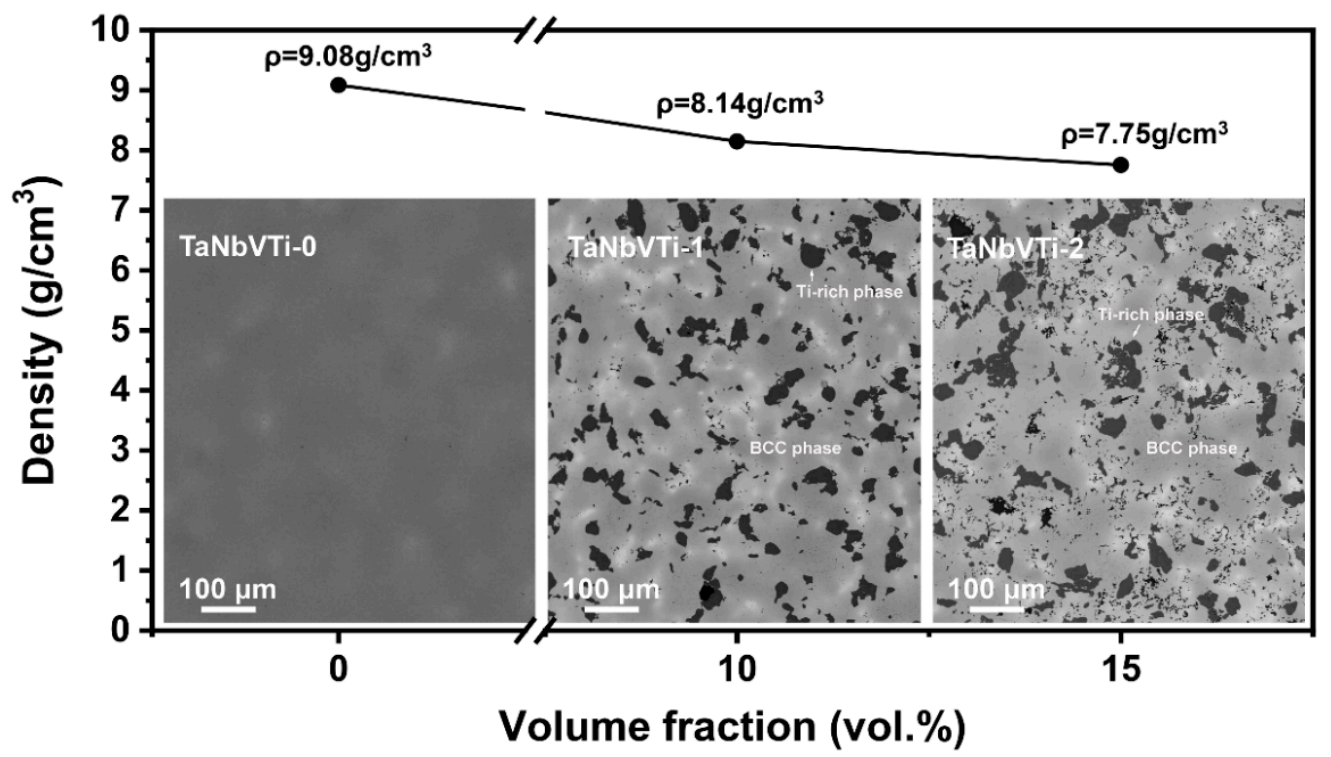

Figure 3. Densities and SEM images of the sintered TaNbVTi-0, TaNbVTi-1 and TaNbVTi-2 RHEAs.

The compressive curves of the TaNbVTi-0, TaNbVTi-1 and TaNbVTi-2 RHEAs are shown in Figure 6a. The yield strength, ultimate strength and the fracture strain of the TaNbVTi-0 RHEA are $1391 \mathrm{MPa}, 1932 \mathrm{MPa}$ and 16.7\%, respectively. And the TaNbVTi-2 RHEA has enhanced yield strength of $1837 \mathrm{MPa}$ and ultimate strength of $2030 \mathrm{MPa}$, but its fracture strain decreases to $11.2 \%$. During the compression testing, no visible damage or macro-crack was observed before attaining the maximum load. Apparently, for the TaNbVTi-1 and the TaNbVTi-2 RHEAs, the introduction of incremental $\mathrm{Al}_{2} \mathrm{O}_{3}$ leads to slight sacrifice in plasticity, but the yield strength and specific yield strength improve significantly, mainly due to the remarkable solid solution strengthening effect caused by $\mathrm{Al}$ in the matrix and the precipitation strengthening effect caused by the $\mathrm{TiO}$ particles. At the same time, the TaNbVTi-2 RHEA exhibits the highest specific yield strength of $237 \mathrm{MPa} \mathrm{cm} / \mathrm{g}$, which is slight higher than that of TaNbVTi-1 RHEA $(217 \mathrm{MPa} \mathrm{cm} / \mathrm{g})$. Figure $6 \mathrm{~b}$ presents fracture strain dependence of compressive specific yield strength of the TaNbVTi-based RHEAs compared with other previously reported typical RHEAs [25,26]. Surprisingly, the results highlight the extraordinary mechanical properties of the TaNbTiV based RHEAs compared with many other previously reported RHEAs with moderate 
plasticity. These exceptional mechanical features suggest a promising method for enhancing RHEAs through the addition of ceramic reinforcements. In addition, the tensile properties of the RHEAs were also tested for comparison, as shown in Table 3. The tensile strength is close to compressive strength, while the tensile elongation is obviously lower than the compressive fracture strain, main due to the stress concentration induced by the $\mathrm{TiO}$ particles during tensile test.

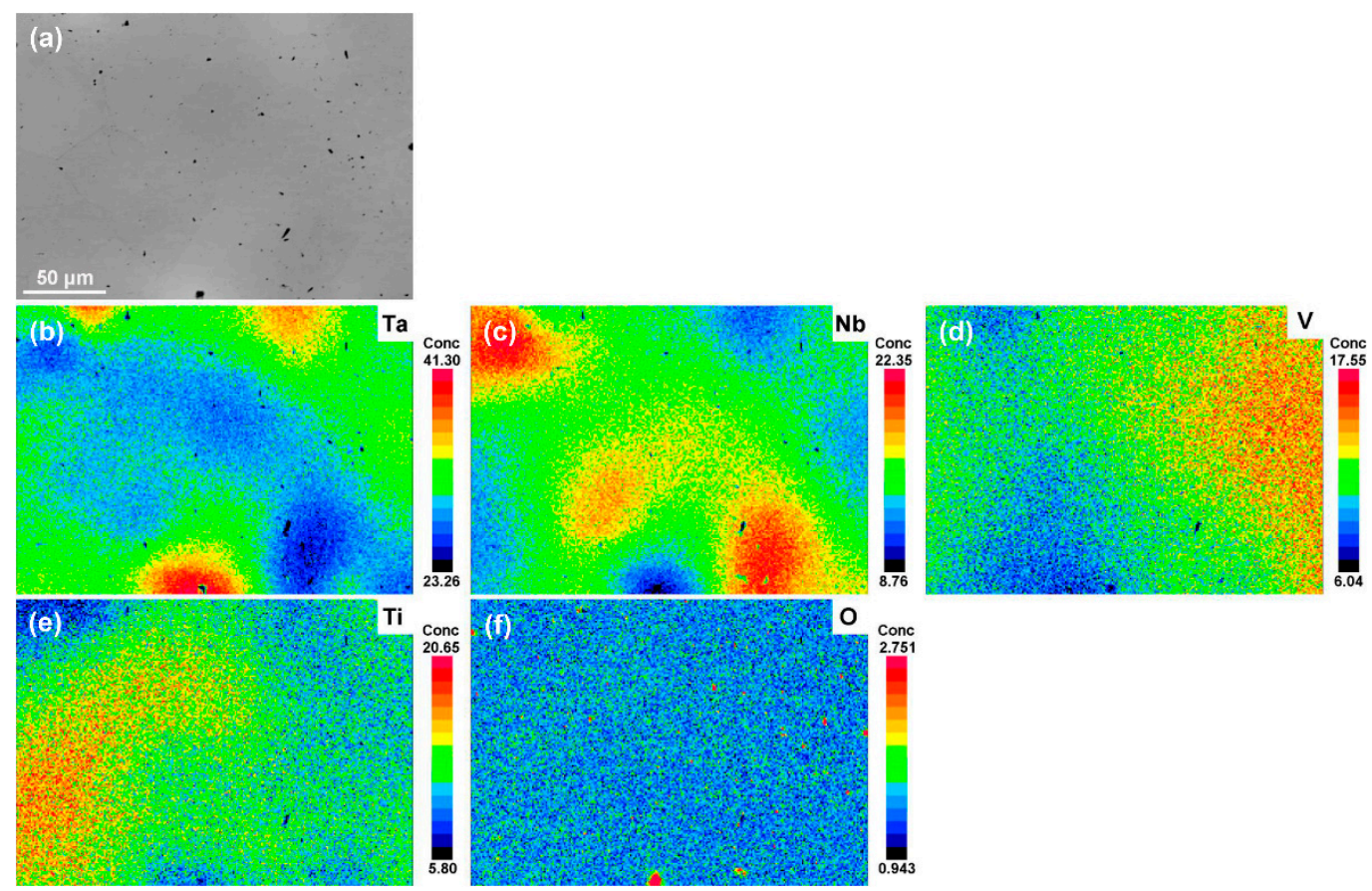

Figure 4. EPMA results of the sintered TaNbVTi-0 RHEA: (a) SEM images; (b-f) distributions of element $\mathrm{Ta}, \mathrm{Nb}, \mathrm{V}, \mathrm{Ti}$ and $\mathrm{O}$.
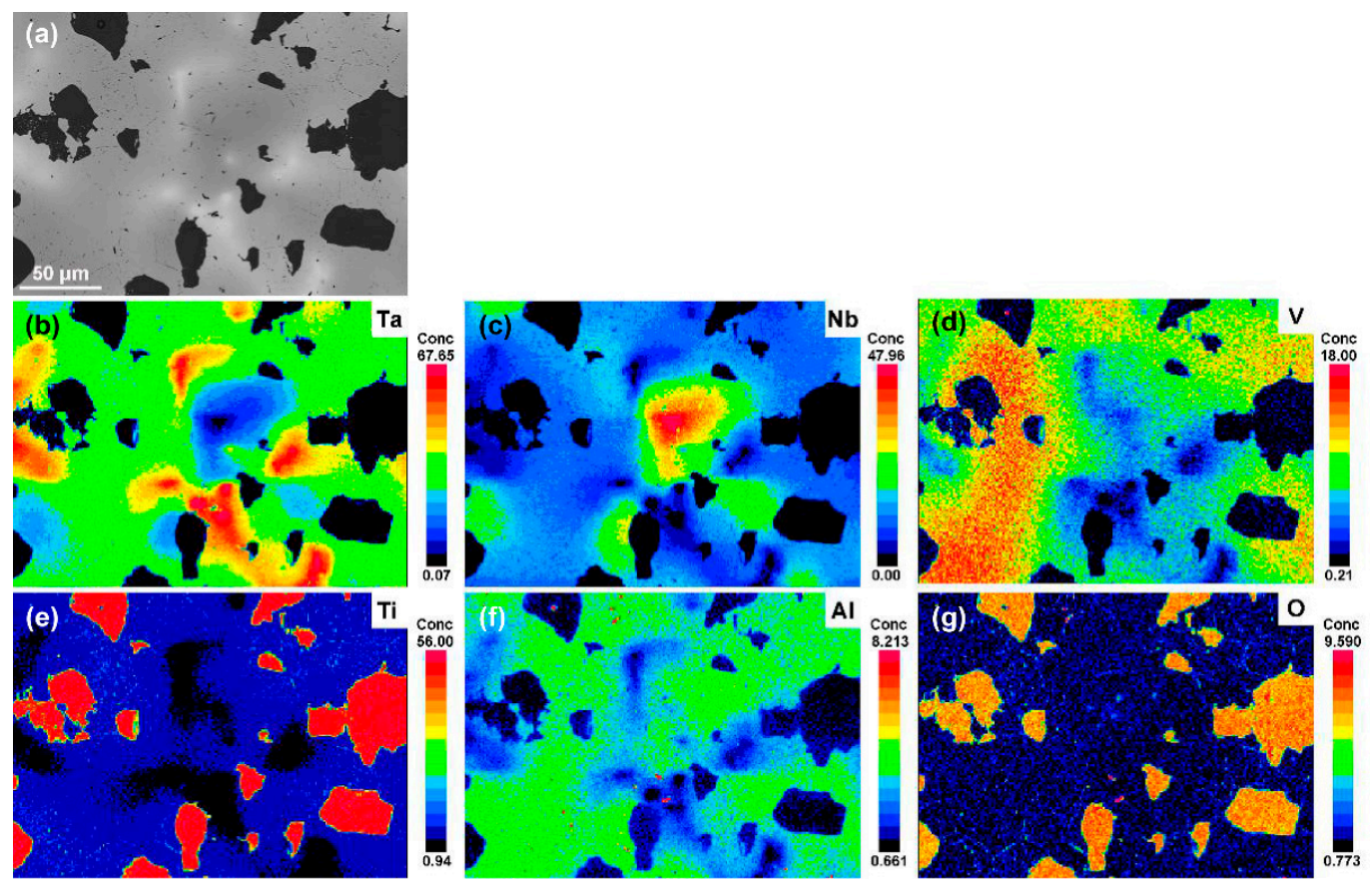

Figure 5. EPMA results of the sintered TaNbVTi-2 RHEA: (a) SEM images; (b-g) distributions of element $\mathrm{Ta}, \mathrm{Nb}, \mathrm{V}, \mathrm{Ti}, \mathrm{Al}$ and $\mathrm{O}$. 

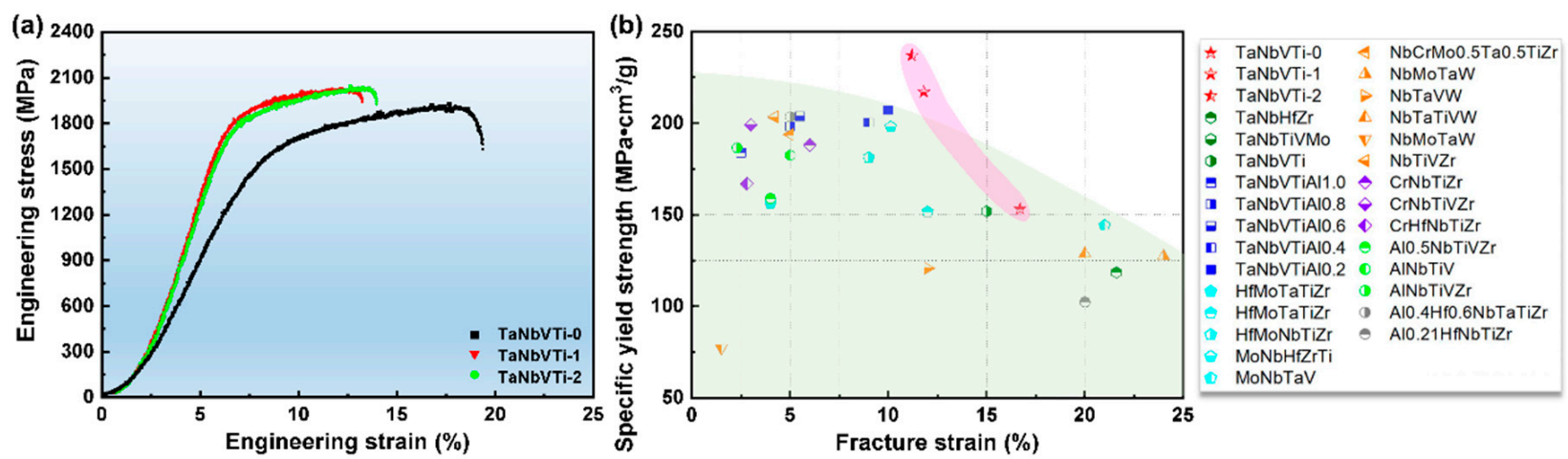

Figure 6. (a) Typical compression engineering stress-strain curves of the sintered TaNbVTi-0, TaNbVTi-1 and TaNbVTi-2 RHEAs; (b) comparison of compressive specific yield strength at room temperature for the current TaNbVTi-based RHEAs and typical RHEAs [25,26].

Table 3. Comparison in compression properties and tensile properties of the TaNbVTi-based RHEAs.

\begin{tabular}{ccccc}
\hline Alloys & $\begin{array}{c}\text { Testing } \\
\text { Method }\end{array}$ & $\begin{array}{c}\text { Yield Strength } \\
\mathbf{( M P a}\end{array}$ & $\begin{array}{c}\text { Fracture Strength } \\
\mathbf{( M P a )}\end{array}$ & $\begin{array}{c}\text { Fracture Strain/ } \\
\text { Elongation (\%) }\end{array}$ \\
\hline TaNbVTi-0 & & 1391 & 1932 & $16 . .7$ \\
TaNbVTi-1 & Compression & 1776 & 2004 & 12.0 \\
TaNbVTi-2 & & 1837 & 2030 & 11.2 \\
\hline TaNbVTi-0 & & 1345 & 1724 & 7.2 \\
TaNbVTi-1 & Tensile & 1694 & 1908 & 2.3 \\
TaNbVTi-2 & & 1762 & 1927 & 2.1 \\
\hline
\end{tabular}

\section{Conclusions}

(1) Novel lightweight TaNbVTi-based RHEAs has been successfully developed through the addition of $\mathrm{Al}_{2} \mathrm{O}_{3}$ ceramic particles. The introduction of $\mathrm{Al}_{2} \mathrm{O}_{3}$ can promotes the formation of $\mathrm{TiO}$ precipitates in the $\mathrm{BCC}$ matrix. Meanwhile, $\mathrm{Al}$ atoms decomposed from $\mathrm{Al}_{2} \mathrm{O}_{3}$ could diffuse and dissolve into the matrix.

(2) The TaNbVTi-2 RHEA has a relative low density of $7.75 \mathrm{~g} / \mathrm{cm}^{3}$ with a high compressive yield strength of $1837 \mathrm{MPa}$, which are 32\% higher and 15\% lower, respectively, compared to the RHEA without $\mathrm{Al}_{2} \mathrm{O}_{3}$ addition. The specific yield strength of TaNbVTi-2 RHEA is better than most reported RHEAs. The newly developed RHEAs are promising for applying in aerospace field (such as aero-engine, nozzle, etc.) due to the high specific strength.

(3) The improved strength is mainly ascribed to the introduction high volume fraction of $\mathrm{Al}_{2} \mathrm{O}_{3}$ additives, resulting in solid solution strengthening and precipitation strengthening. Moreover, the ductile matrix is responsible for the good compressive plasticity.

Author Contributions: A.F.: Methodology, Investigation, Visualization, Formal analysis, Writingoriginal draft. Y.C.: Funding acquisition, Project administration, Supervision. Y.L.: Investigation, Writing-review \& editing. S.X.: Investigation. All authors have read and agreed to the published version of the manuscript.

Funding: This work was supported by the Science and Technology Innovation Program of Hunan Province [No. 2020RC2007] and the National Natural Science Foundation of China [No. 52104365].

Institutional Review Board Statement: Not applicable.

Informed Consent Statement: Not applicable.

Data Availability Statement: The data presented in this study are available on request from the corresponding author.

Conflicts of Interest: The authors declare no conflict of interest. 


\section{References}

1. Zhang, Y.; Zuo, T.T.; Tang, Z.; Gao, M.C.; Dahmen, K.A.; Liaw, P.K.; Lu, Z.P. Microstructures and properties of high-entropy alloys. Prog. Mater. Sci. 2014, 61, 1-93. [CrossRef]

2. Lei, Z.; Liu, X.; Wu, Y.; Wang, H.; Jiang, S.; Wang, S.; Hui, X.; Wu, Y.; Gault, B.; Kontis, P.; et al. Enhanced strength and ductility in a high-entropy alloy via ordered oxygen complexes. Nature 2018, 563, 546-550. [CrossRef]

3. Zou, Y.; Maiti, S.; Steurer, W.; Spolenak, R. Size-dependent plasticity in an $\mathrm{Nb}_{25} \mathrm{Mo}_{25} \mathrm{Ta}_{25} \mathrm{~W}_{25}$ refractory high-entropy alloy. Acta Mater. 2014, 65, 85-97. [CrossRef]

4. Fu, A.; Liu, B.; Lu, W.; Liu, B.; Li, J.; Fang, Q.; Li, Z.; Liu, Y. A novel supersaturated medium entropy alloy with superior tensile properties and corrosion resistance. Scr. Mater. 2020, 186, 381-386. [CrossRef]

5. Klimova, M.; Stepanov, N.; Shaysultanov, D.; Chernichenko, R.; Yurchenko, N.; Sanin, V.; Zherebtsov, S. Microstructure and mechanical properties evolution of the $\mathrm{Al}, \mathrm{C}$-containing $\mathrm{CoCrFeNiMn-type} \mathrm{high-entropy} \mathrm{alloy} \mathrm{during} \mathrm{cold} \mathrm{rolling.} \mathrm{Materials} \mathrm{2018,}$ 11, 53. [CrossRef]

6. Zhang, H.; Zhao, Y.; Huang, S.; Zhu, S.; Wang, F.; Li, D. Manufacturing and analysis of high-performance refractory high-entropy alloy via selective laser melting (SLM). Materials 2019, 12, 720. [CrossRef] [PubMed]

7. Senkov, O.N.; Senkova, S.V.; Woodward, C.; Miracle, D.B. Low-density, refractory multi-principal element alloys of the Cr-Nb-TiV-Zr system: Microstructure and phase analysis. Acta Mater. 2013, 61, 1545-1557. [CrossRef]

8. Guo, W.; Liu, B.; Liu, Y.; Li, T.; Fu, A.; Fang, Q.; Nie, Y. Microstructures and mechanical properties of ductile NbTaTiV refractory high entropy alloy prepared by powder metallurgy. J. Alloys Compd. 2019, 776, 428-436. [CrossRef]

9. Juan, C.C.; Tsai, M.H.; Tsai, C.W.; Lin, C.M.; Wang, W.R.; Yang, C.C.; Chen, S.K.; Lin, S.J.; Yeh, J.W. Enhanced mechanical properties of HfMoTaTiZr and HfMoNbTaTiZr refractory high-entropy alloys. Intermetallics 2015, 62, 76-83. [CrossRef]

10. Roh, A.; Kim, D.; Nam, S.; Kim, D.I.; Kim, H.Y.; Lee, K.A.; Choi, H.; Kim, J.H. NbMoTaW refractory high entropy alloy composites strengthened by in-situ metal-non-metal compounds. J. Alloys Compd. 2020, 822, 153423. [CrossRef]

11. Kvashnin, A.G.; Tantardini, C.; Zakaryan, H.A.; Kvashnina, Y.A.; Oganov, A.R. Computational Search for New W-Mo-B Compounds. Chem. Mater. 2020, 32, 7028-7035. [CrossRef]

12. Wang, Q.; Han, J.; Liu, Y.; Zhang, Z.; Dong, C.; Liaw, P.K. Coherent precipitation and stability of cuboidal nanoparticles in body-centered-cubic $\mathrm{Al}_{0.4} \mathrm{Nb}_{0.5} \mathrm{Ta}_{0.5} \mathrm{TiZr}_{0.8}$ refractory high entropy alloy. Scr. Mater. 2021, 190, 40-45. [CrossRef]

13. Bai, Z.C.; Ding, X.F.; Hu, Q.; Yang, M.; Fan, Z.T.; Liu, X.W. Unique deformation behavior and microstructure evolution in high-temperature processing of a low-density $\mathrm{TiAlVNb}_{2}$ refractory high-entropy alloy. J. Alloys Compd. 2021, 885, 160962. [CrossRef]

14. Liu, X.W.; Bai, Z.C.; Ding, X.F.; Yao, J.Q.; Wang, L.; Su, Y.Q.; Fan, Z.T.; Guo, J.J. A novel light-weight refractory high-entropy alloy with high specific strength and intrinsic deformability. Mater. Lett. 2021, 287, 129255. [CrossRef]

15. Chen, Y.; Xu, Z.; Wang, M.; Li, Y.; Wu, C.; Yang, Y. A single-phase $\mathrm{V}_{0.5} \mathrm{Nb}_{0.5}$ ZrTi refractory high-entropy alloy with outstanding tensile properties. Mater. Sci. Eng. A 2020, 792, 139774. [CrossRef]

16. Senkov, O.N.; Senkova, S.V.; Woodward, C. Effect of aluminum on the microstructure and properties of two refractory highentropy alloys. Acta Mater. 2014, 68, 214-228. [CrossRef]

17. Yang, X.; Zhang, Y.; Liaw, P.K. Microstructure and compressive properties of $\mathrm{NbTiVTaAl}_{\mathrm{x}}$ high entropy alloys. Procedia Eng. 2012, 36, 292-298. [CrossRef]

18. Xin, C.; Liu, W.; Li, N.; Yan, J.; Shi, S. Metallization of $\mathrm{Al}_{2} \mathrm{O}_{3}$ ceramic by magnetron sputtering Ti/Mo bilayer thin films for robust brazing to Kovar alloy. Ceram. Int. 2016, 42, 9599-9604. [CrossRef]

19. Guo, Y.; Li, M.; Li, P.; Chen, C.; Zhan, Q.; Chang, Y.; Zhang, Y. Microstructure and mechanical properties of oxide dispersion strengthened FeCoNi concentrated solid solution alloys. J. Alloys Compd. 2020, 820, 153104. [CrossRef]

20. Yamashita, S.; Ohtsuka, S.; Akasaka, N.; Ukai, S.; Ohnuki, S. Formation of nanoscale complex oxide particles in mechanically alloyed ferritic steel. Philos. Mag. Lett. 2004, 84, 525-529. [CrossRef]

21. He, P.; Gao, P.; Tian, Q.; Lv, J.; Yao, W. An in situ SANS study of nanoparticles formation in 9Cr ODS steel powders. Mater. Lett. 2017, 209, 535-538. [CrossRef]

22. Cao, Y.; Zhang, W.; Liu, B.; Liu, Y.; Du, M.; Fu, A. Phase decomposition behavior and its effects on mechanical properties of $\mathrm{TiNbTa}_{0.5} \mathrm{ZrAl}_{0.5}$ refractory high entropy alloy. J. Mater. Sci. Technol. 2021, 66, 10-20. [CrossRef]

23. Fan, Q.C.; Li, B.S.; Zhang, Y. The microstructure and properties of $(\mathrm{FeCrNiCo}) \mathrm{Al}_{\mathrm{x}} \mathrm{Cu}_{\mathrm{y}}$ high-entropy alloys and their TiC-reinforced composites. Mater. Sci. Eng. A 2014, 598, 244-250. [CrossRef]

24. Agustianingrum, M.P.; Yoshida, S.; Tsuji, N.; Park, N. Effect of aluminum addition on solid solution strengthening in CoCrNi medium-entropy alloy. J. Alloys Compd. 2019, 781, 866-872. [CrossRef]

25. Miracle, D.B.; Senkov, O.N. A critical review of high entropy alloys and related concepts. Acta Mater. 2017, 122, 448-511. [CrossRef]

26. Couzinié, J.P.; Senkov, O.N.; Miracle, D.B.; Dirras, G. Comprehensive data compilation on the mechanical properties of refractory high-entropy alloys. Data Brief 2018, 21, 1622-1641. [CrossRef] 